\title{
Ivan Ferenčak
}

Hrvatska akademija znanosti i umjetnosti, Strossmayerova galerija starih majstora

\section{O provenijenciji nekoliko umjetnina iz Muzeja Mimara u Zagrebu}

\author{
Izvorni znanstveni rad - Original scientific paper \\ Primljen - Received 4. 6. 2021. \\ UDK 069.51Mimara(497.5Zagreb) \\ DOI https://doi.org/10.31664/ripu.2021.45.18
}

\begin{abstract}
Sažetak
U radu se za odabranih šest umjetnina iz Muzeja Mimara u Zagrebu donose podatci o ranijoj provenijenciji, mogućim okolnostima prelaska u ruke Ante Topića Mimare te općenito o njihovu povijesnoumjetničkom vrednovanju. Putem utvrđenog mjesta na tržištu i transfere predmeta
\end{abstract}

ujedno se ocrtava Topićeva aktivnost tijekom 30-ih i 40-ih godina 20. stoljeća. Upućuje se na aktere od kojih je Topić posredno ili izravno nabavljao umjetnine te se apostrofiraju utvrdene ranije zbirke kojima su djela pripadala.

Ključne riječi: Muzej Mimara, Ante Topić Mimara, privatne zbirke, provenijencija umjetnina, tržište umjetnina

Muzej Mimara u Zagrebu utemeljen je na zbirci koju je kolekcionar Ante Topić Mimara (1898. - 1987.) darovao državi. U listopadu 1973. godine potpisao je darovni ugovor koji je dodatkom 1986. godine proširio za više od tisuću umjetnina, pa je njegova donacija nakon otvaranja Muzeja u srpnju 1987. godine u konačnici obuhvaćala više od 3500 predmeta. ${ }^{1}$

Unatoč stalnome postavu brojne i raznovrsne građe, Muzej se u inozemnim stručnim krugovima - iako bez dostatnih znanstvenih utemeljenja i elaboriranih potkrepa takvih tvrdnji - često apostrofira kao zbirka krivotvorina ili opljačkanih umjetnina, a donator smatra oportunistom ratnih stradanja. ${ }^{2}$ Suočavanju $s$ takvom percepcijom nipošto ne pogoduju brojne nepoznanice iz Topićeve biografije i njegova nevoljkost da rasvijetli vlastitu kolekcionarsku aktivnost, kao i još uvijek uvelike nerazjašnjena provenijencija niza umjetnina iz muzeja koji nosi njegovo ime. Potpuna provenijencija u kojoj je smjene vlasnika moguće pratiti od nastanka djela do današnjega smještaja nije učestala i u pravilu je povezana s proslavljenim umjetninama uključenima u znamenite, ponajprije vladarske zbirke. U slučaju Topićevih umjetnina, međutim, izostaje čak i ona prva karika prije realizirane donacije - gdje je i kada, od koga i u kojim okolnostima donator nabavio koje djelo.
Podrijetlo više slika iz Muzeja Mimara u nekoliko je radova već 1980 -ih naznačio Slavko Šterk, s jedne strane pozivajući se na informacije pribavljene od donatora, a s druge referirajući se na prodajne kataloge iz 20. stoljeća. ${ }^{3}$ Okolnosti nabave ili ranija provenijencija kasnije su utvrđene za još nekoliko umjetnina, no takvi istraživački postupci koncentrirani na utvrđivanje prethodnih vlasnika i kretanju predmeta iz Muzeja Mimara ostali su izolirani primjeri. ${ }^{4}$ Nepoznata provenijencija podjednako je opterećivala i brojem znatno manju skupinu umjetnina koje su iz Topićeve zbirke prispjele u Strossmayerovu galeriju starih majstora HAZU nakon sklapanja darovnoga ugovora 1967. godine. Recentnim usmjerenim istraživanjima za dobar su broj tih slika utvrđene okolnosti u kojima ih je Topić nabavljao na tržištu Trećeg Reicha i u kojima je formirao svoju zbirku. ${ }^{5}$ Gotovo svu građu koja je dospjela u Strossmayerovu galeriju Topić je skupio prije 1948. godine kada je predmete dokumentirao u trima fotoalbumima naslovljenima Zbirka slika i skulptura Ante Mimara. ${ }^{6}$ Za razliku od tih umjetnina, djela koja se nalaze u Muzeju Mimara nedvojbeno su skupljana i kasnijih godina. Primjerice, katalonskom majstoru 15. stoljeća pripisano Navještenje Šterk je prepoznao na njemačkim aukcijama 1955. i 1962. godine, a ikonu s likom sv. Ivana 
Krstitelja u prodajnome katalogu minhenske Galerie Ilas Neufert iz 1962. godine. ${ }^{7}$

Nekoliko ovdje okupljenih primjera ukazuje da se u Muzeju Mimara nalaze i umjetnine koje je donator raznim kanalima zasigurno nabavio tijekom 1930-ih i 1940-ih, dakle u vrijeme kada je skupljao umjetnine od kojih je tek dio 1948. godine uvrstio u svoju fotoalbumima dokumentiranu zbirku. U fotoalbumima je, naime, zastupljeno stotinu četrdeset umjetnina, no u literaturi su prisutne, kako se čini, proizvoljne procjena opsega Topićeve zbirke: Vesna Kusin piše da je krajem Drugoga svjetskog rata posjedovao oko 300 umjetnina, dok Andrew Decker navodi da je njegova zbirka 1948. godine obuhvaćala oko 420 umjetnina. ${ }^{8} \mathrm{Za}$ izabranih šest predmeta iz Muzeja Mimara ovim su radom utvrđene pojedinosti o ranijoj provenijenciji, a temeljem tih novoutvrđenih podataka ujedno su proširene spoznaje o Topićevim mehanizmima i načinima nabavljanja umjetnina.

\section{Aukcijske prodaje 1930-ih}

U četvrtom desetljeću 20. stoljeća na njemačkome tržištu umjetnina bile su prisutne barem dvije slike iz Muzeja Mimara. Sliku talijanskoga renesansnog majstora Giuliana Bugiardinija (1475. - 1554.) Bogorodica s Djetetom (sl. 1) Slavko Šterk prepoznao je u aukcijskome katalogu Sammlung Geheimrat Ottmar Strauss, II. Teil (...) iz 1935. godine (sl. 2a, b) i tu je prodaju pretpostavio kao Topićevu akviziciju. ${ }^{9}$ Raniji vlasnik te slike u popisu konsignatora (Verzeichnis der Besitzer) obilježen je slovom C., a od toga neimenovanog pojedinca na aukciji ponuđena je još samo jedna slika, također talijanske renesanse. ${ }^{10}$ Obje slike prodane su na aukciji pri čemu je zagrebačka postigla iznos od $2900 \mathrm{RM}$, što u relaciji s cijenama na berlinskome tržištu te godine ulazi u kategoriju visokih cijena. ${ }^{11}$

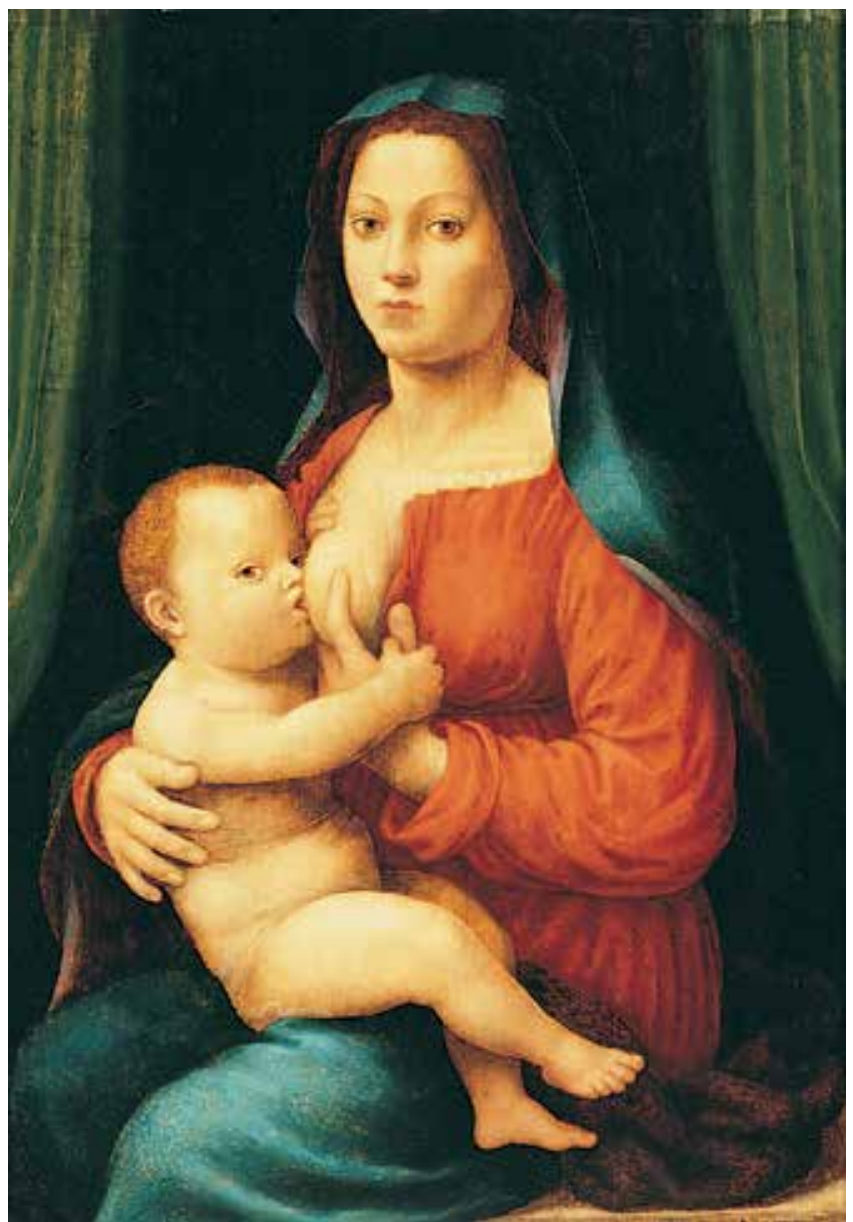

1. Giuliano Bugiardini, Bogorodica s Djetetom, o. 1520., ulje na dasci, $73,3 \times 49,5 \mathrm{~cm}$, Zagreb, Muzej Mimara, inv. br. ATM 875 (@) Dokumentacija Muzeja Mimara, foto: Nenad Čaće)

Giuliano Bugiardini, The Virgin and Child, ca. 1520, oil on panel, $73.3 \times 49.5 \mathrm{~cm}$, Zagreb, Mimara Museum, inv. no. ATM 875
Istih se godina na njemačkome tržištu našao triptih sa slikom Kristova silaska u Limb (sl. 3) koji je Topić držao autografom Hieronymusa Boscha (oko 1450. - 1516.). ${ }^{12}$ Središnje polje triptiha s prizorom Kristova silaženja u carstvo mrtvih inačica je slike Kristov silazak u Limb iz Philadelphia Museum of Art,

2. Aukcijski katalog Sammlung Geheimrat Ottmar Strauss, Teil II (...), Frankfurt, 22.-24. svibnja 1935.: a) str. 7, b) tabl. 11 (izvor: https:// digi.ub.uni-heidelberg.de/diglit/ helbing1934_11_06bd2/0012/image; https://digi.ub.uni-heidelberg.de/ diglit/helbing1934_11_06bd2/0110/ image)

Auction catalogue Sammlung Geheimrat Ottmar Strauss, Teil II (...), Frankfurt, May 22-24, 1935: a) p. 7, b) table 11
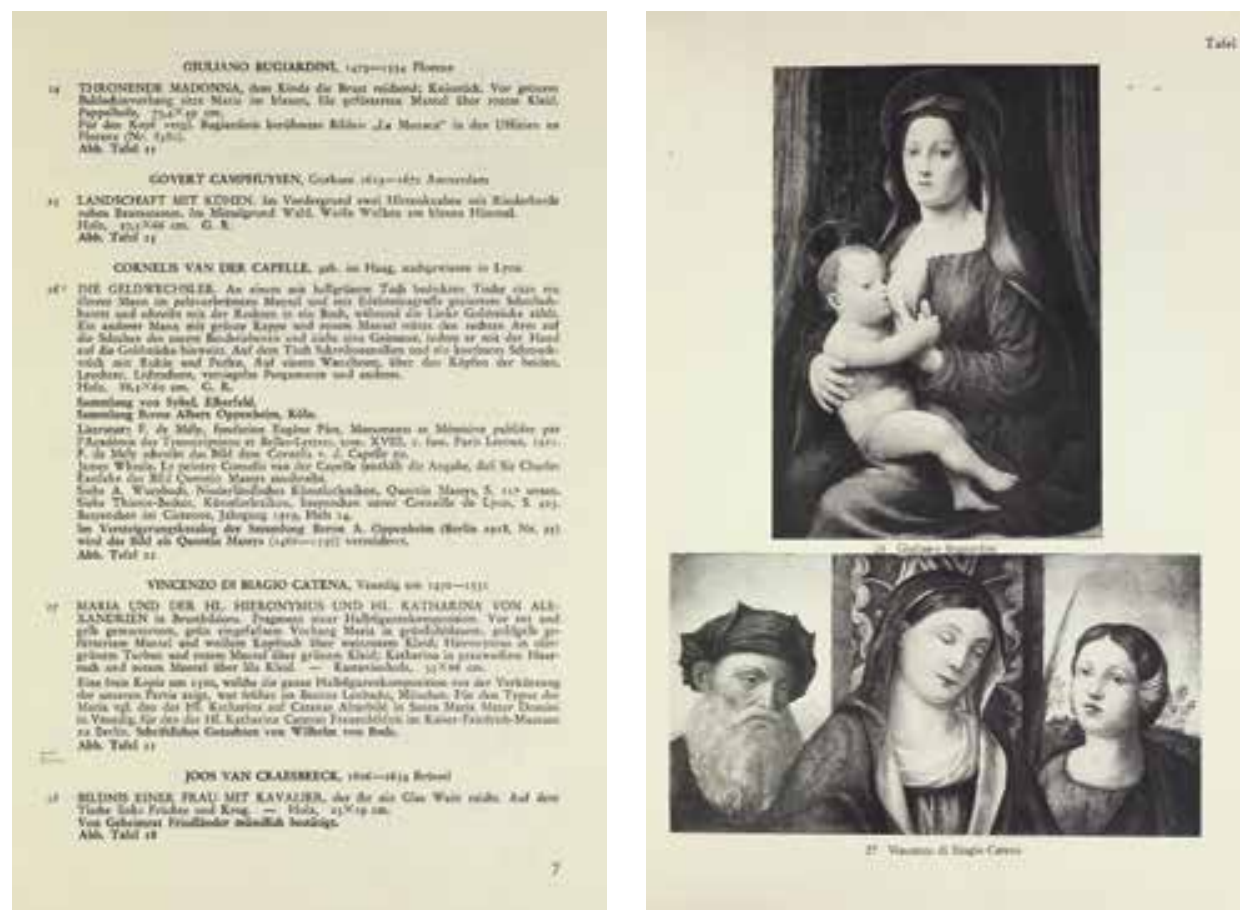


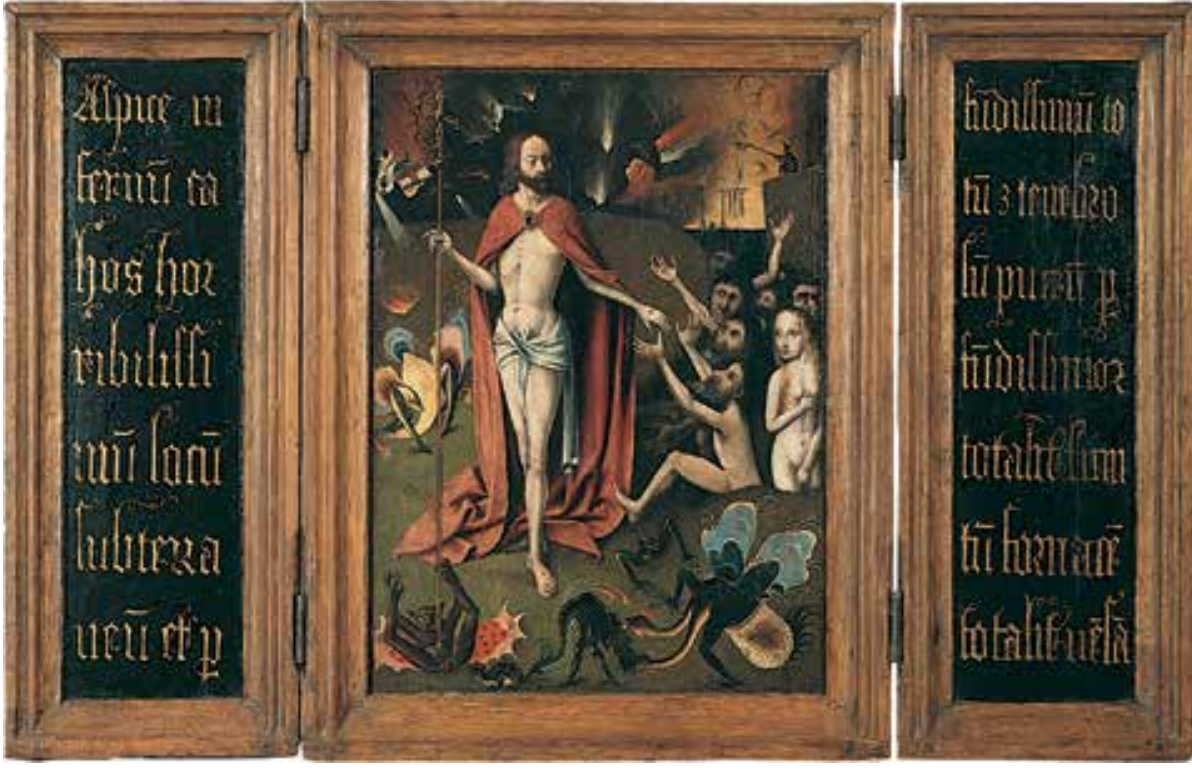

3. Sljedbenik Hieronymusa Boscha, Triptih Kristova silaska u Limb, 16. st. (?), ulje na dasci, $48,6 \times 76 \mathrm{~cm}$ (rastvoren), Zagreb, Muzej Mimara, inv. br. ATM 937 (@ Dokumentacija Muzeja Mimara, foto: Nenad Čaće)

Follower of Hieronymus Bosch, triptych Christ's Descent into Limbo, $16^{\text {th }} c$. (?), oil on panel, 48.6 $\times 76 \mathrm{~cm}$ (opened), Zagreb, Mimara Museum, inv. no. ATM 937

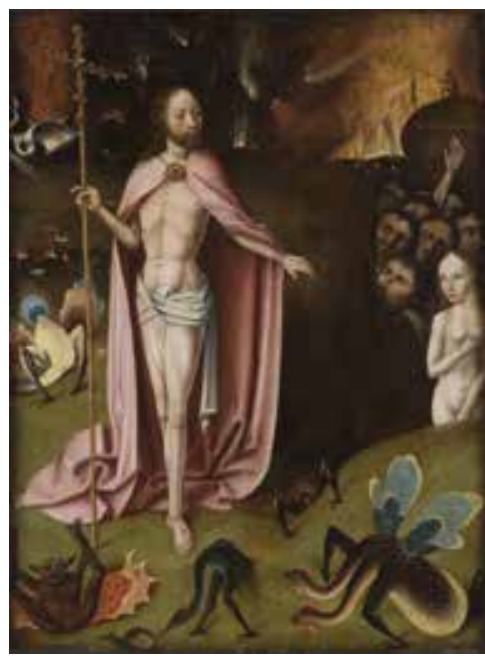

4. Sljedbenik Hieronymusa Boscha, Kristov silazak u Limb, 16. st., ulje na dasci, 54,6 × 41,4 cm, Philadelphia Museum of Art, inv. br. 2055 (izvor: https://commons.wikimedia.org/wiki/ File:Bosch_follower_Christ_in_Limbo_Philadelphia.jpg)

Follower of Hieronymus Bosch, Christ's Descent into Limbo, $16^{\text {th }}$ century, oil on panel, $54.6 \times 41.4 \mathrm{~cm}$, Philadelphia Museum of Art, inv. no. 2055 pripisane Boschevu sljedbeniku (sl. 4) ${ }^{13}$ od koje je razlikuje nekoliko segmenata. Obrisna figura vraga, koji sjedi i "peca" duše uz vješala u gornjemu desnom uglu, na filadelfijskoj je slici na predimenzioniranom oblutku preko kojega je ispisana signatura $P$. CHRISTOPSEN $\cdot M \cdot F \cdot$, dok je na zagrebačkoj slici ta figura smještena na kubusu, a Kristov križ koji je na filadelfijskoj slici oslonjen o tlo i baca sjenu, na zagrebačkoj udara krilatog demona. Upadljivije je odstupanje i različit hibrid uza sam rub slike. Čitav lik Adama kojemu Krist pruža ruku, kao i ruka koju drugi muškarac iz Limba pruža prema Kristu na filadelfijskoj su slici preslikani te se tek naziru njihovi obrisi. Kao rezultat interdisciplinarnoga znanstvenog projekta Bosch Research and Conservation Project opus slikara i njegove radionice nedavno je temeljito revaloriziran, a u toj evaluaciji Boscheva stvaralaštva ni filadelfijska slika ni triptih iz Muzeja Mimara nisu pronašli svoje mjesto. ${ }^{14}$ Ipak, motivima fantastičnih bića okupljenih u prednjem prostornom pojasu obje slike neupitno odražavaju Boschev slikarski leksik.

Središnja slika triptiha šarnirima je povezana s uskim vratnicama. Na njihovoj unutrašnjoj strani zlatnim je slovima gotice na crnoj podlozi ispisan tekst preuzet iz XXI. poglavlja traktata De spiritualibus ascensionibus nizozemskoga mistika i dionika pokreta moderne pobožnosti (Devotio moderna) Gerarda Zerbolta van Zutphena (1367. 1398.): »Aspice infernu[m] cahos [sic!] horribilissimu[m] locu $[\mathrm{m}]$ subterraneu $[\mathrm{m}]$ et $\mathrm{p}[\mathrm{ro}] \mathrm{fu}[\mathrm{n}]$ dissimu $[\mathrm{m}]$ totu $[\mathrm{m}]$ \& tenebrosu[m] puteu[m] p[ro]fu[n]dissimor[um] totalit[er] hiantu[m] fornace $[\mathrm{m}]$ totalit $[\mathrm{er}]$ nefa ${ }^{15}$
Specifičnim integriranjem kompozicije Kristov silazak $u$ Limb s tekstom ispisanim zlatnim slovima na crnoj podlozi krila, triptih u potpunosti odgovara djelu opisanom kao rad Boscheve radionice u prodajnome katalogu Gemälde alter und neuerer Meister, Antiquitäten (...) berlinske aukcijske kuće Lepke iz prosinca 1936. godine:

87. HIERONYMUS BOSCH, WERKSTATT: TRIPTYCHON. Mittelbild: Christus in der Vorhölle. Christus in weitem Purpurmantel steht als Sieger in der von phantastischen Tieren bevölkerten Hölle, in der Rechten hält er die kreuzgekrönte gold[e]ne Lanze und sticht einen Teufel, die Linke streckt er Adam entgegen, der ihm mit anderen Propheten die Hände entgegenstreckt; neben ihm Eva. Der Hintergrund voll höllischer Feuerszenen. - Die Seitenflügel mit goldenem Text auf schwarzem Grund. Originaler Holzrahmen. Maße des Mittelbildes: $40 \times 30 \mathrm{~cm} .{ }^{16}$

Na ovoj aukcijskoj prodaji Iva Pasini Tržec ranije je uočila sliku Slikarski atelje za koju je sugerirala da je moguće riječ o djelu iz Topićeve donacije Strossmayerovoj galeriji, odnosno o slici dokumentiranoj 1928. godine u zbirci H. C. Boysen u Berlinu. ${ }^{17}$ Prisutnost više djela iz Topićeva vlasništva na istoj aukciji ide u prilog pretpostavci da su akvizicije za njegovu zbirku uistinu realizirane u tome trenutku, a takvi su primjeri zabilježeni u još nekoliko slučajeva slika iz Strossmayerove galerije. $^{18}$

Ograničena saznanja o ranijim vlasnicima i tijeku aukcije na kojoj su se našli Slikarski atelje i triptih Kristova silaska $u$ Limb pruža nam anotirani primjerak kataloga aukcije sačuvan u knjižnici RKD-a, Nizozemskog instituta za povijest 
umjetnosti u Den Haagu. ${ }^{19}$ Slika iz Strossmayerove galerije prema tiskanom popisu potječe od konsignatora označenog kraticom St. Anotacije u haškom primjerku kataloga ovog konsignatora identificiraju kao Stöhr (?), a uz njegovo je ime zabilježen broj 1927, ispisan i na poleđini slike iz Galerije. Čini se, međutim, da je prilikom pripremanja i izrade kataloga došlo do (tiskarske) pogreške. Nakon kataloške jedinice Slikarskoga ateljea u katalogu se nastavlja skupina slika čiji je konsignator - u popisu predstavljen kao Bo. - anotacijom identificiran kao Boysen u čijoj je zbirci Slikarski atelje ranije dokumentiran, pa je vjerojatno "linija razgraničenja" dvaju konsignatora omaškom pogrešno "podvučena". Raniji vlasnik triptiha iz Muzeja Mimara - u popisu konsignatora obilježen kraticom $B r$. - rukopisnom je bilješkom identificiran kao Brendel i uz njegovo je ime zabilježen broj 1915, a na aukciji je sudjelovao s ukupno četiri slike. ${ }^{20}$

Dvije slike iz Muzeja Mimara identificirane na aukcijskim prodajama sredinom 1930-ih proširuju spoznaje o Topićevu kolekcionarstvu u ranom razdoblju. Dočim su dva primjera iz Muzeja kao dio Topićeve zbirke javno predstavljene tek 1983. godine na izložbi u vili Zagorje, ${ }^{21}$ za Slikarski atelje iz Strossmayerove galerije potvrdu njegova vlasništva već 1948 . godine pronalazimo u fotoalbumima kojima je, evidentno, dokumentirao tek dio umjetnina koje je tada posjedovao.

\section{Akvizicije slika 1940-ih}

Kontinuiranu Topićevu skupljačku aktivnost na njemačkome prostoru u ratom obilježenoj prvoj polovini 1940-ih potvrđuju ponajprije identificirani primjeri iz Strossmayerove galerije. ${ }^{22}$ Umjetnine je nastavio sakupljati i u poslijeratnim godinama, ${ }^{23}$ a dosad utvrđenim djelima koja je pribavio nakon Drugoga svjetskog rata možemo priključiti još dvije slike iz Muzeja Mimara.

Sredinom 1940-ih Topićev se alias u kontekstu kupoprodaje slika spominje u izvještaju Renéa Françoisa Paula de Beauforta (1889. - 1969.), od sredine 1946. godine šefa nizozemske delegacije za restituciju umjetnina pri Central Collecting Pointu u Münchenu. ${ }^{24} \mathrm{U}$ izvještaju o putovanju u Nürnberg i Hersbrück 27. studenoga 1946., između ostalih susreta u Hersbrücku, De Beaufort navodi i onaj s izvjesnim K. Arndtom: »...Then I saw Mr. .K. ARNDT, Kellerstrasse 16. He told me: (...) A painting by Troyon, Landscape and an other by Weissenbruch: Market in a village, he sold to a certain Franz Mimara at Berlin, but couldn't remember anymore the right address. ${ }^{25}$

Obje ove slike Fondacija za vlasništvo nizozemskih umjetnina (Stichting Nederlands Kunstbezit, skraćeno SNK) zabilježila je već i prije De Beaufortova izvještaja u tzv. internim obrascima za izjave o smještaju umjetnina. Nakon Drugoga svjetskog rata, naime, osobe kojima su okupatori oduzeli umjetnine, odnosno pojedinci koji su raspolagali informacijama o umjetninama koje su iz Nizozemske dospjele u ruke neprijatelja - neovisno o tome je li do transfera umjetnine (i vlasništva) došlo svojevoljno ili prisilno - bili su dužni obavijesti SNK putem obrasca s izjavom. ${ }^{26}$ Izjave o slikama koje Arndt navodi u dva je navrata krajem 1945. godine pružio Dirk Albert Hoogendijk (1895. - 1975.), nizozemski trgovac umjetnina koji je u vrijeme okupacije umjetnine prodavao nacistima, između ostalih, i redovitom posjetitelju njegove amsterdamske firme Kunsthandel D. A. Hoogendijk \& Co. Hermannu Göringu. ${ }^{27} \mathrm{Za}$ obje je slike Hoogendijk izjavio da su se ranije nalazile u njegovu vlasništvu, a da ih je »dobrovoljno prodao « (vrijwillige verkoop) Karlu Arndtu iz Hersbrücka. ${ }^{28} \mathrm{U}$ opisu Troyonova rada Landschap met Christus aan de bron naveo je podatke o dimenzijama (30 $\times 40 \mathrm{c}$ ), nosiocu (Panell /misschien doek/) te napomenuo da je slika cjelovito signirana (Voluit geteekend), a kao njeno podrijetlo naveo je "posredovanje» (tusschendandel).

Kolacioniranjem tih izvora, djelo barbizonskog slikara Constanta Troyona (1810. - 1865.) koje je Arndt prodao »Franzu Mimari« prepoznajemo u slici Krist i Samaritanka (sl. 5) iz Muzeja Mimara: podudarne je biblijske ikonografije, također je signirana te je usporedivih dimenzija i nosioca. Pritom, to se djelo izdvaja kao jedinstveni primjer umjetnine čiji je današnji smještaj poznat, a za koju postoje arhivski podatci o izravnoj Topićevoj akviziciji.

Krajem 1940-ih i tijekom 1950. godine Topić je bio intenzivno involviran u dopremanje umjetnina iz Njemačke u Jugoslaviju i u tim je podvizima blisko surađivao s jugoslavenskim državnim vrhom. O svojim nabavama umjetnina izvještavao je Josipa Broza Tita, a s obzirom na sadržaj sačuvanih pisama, izvjesno je kako je Topić u nekim od tih akvizicija djelovao kao "kupac" u Titovoj službi. ${ }^{29} \mathrm{U}$ ožujku 1950. godine o transportiranju nabavljenih slika iz Berlina u Beograd obavijestio je Tita: »Ja sam Vam poslao prošloga mjeseca 28 slika iz Berlina, nadam se da su u redu došle u Beograd. Imena autora poslaću Vam skoro. Jasam (!) te slike kupio iz onoga novca kojeg ste mi Vi lično dali, prama tome te slike su Vaše. Želio bi da Vam skrenem pažnju na sliku od Gerarda van Eckheuta (!), najboljeg Rembrandtova prijatelja i saradnika. Davanje Desetine, to je glavno djelo majstorovo. Ta sama slika vredi triputa više nego što sam ja platio za svi (!) 30 slika. « ${ }^{30}$

Kasnije je Topić tvrdio kako je umjetnine poslane u veljači 1950. godine namijenio kao dar Strossmayerovoj galeriji, ${ }^{31}$ no komparativnom analizom arhivske građe taj je transfer - jer je riječ o slikama koje je kupovao za Tita osobno i njegovim novcem - u novije vrijeme osporen kao Topićev dar. ${ }^{32}$

U sklopu tog transfera Topić je u više pisama kustosu i ravnatelju Strossmayerove galerije Vinku Zlamaliku istaknuo sliku Ruta i Boaz (sl. 6) nizozemskog majstora Gerbranda van den Eeckhouta (1621. - 1674.): »Među onih 20 slika u B. D. [i.e. Belom dvoru] sigurno znam da se nalazi glavni rad od G. v. Eckhaut "Ruth und Boas" podpisana i datirana 1661. (33 $^{33}$

Pobliže okolnosti u kojima je Topić došao u posjed slike - kao i za čitav niz drugih djela - nije zasad moguće dokumentirano utvrditi, no jedno od Topićevih pisama otvara dosta izglednu mogućnost da ju je nabavio u posljednjim mjesecima 1948. godine; u siječnju 1949. godine Titu piše: »Ja sam od moga odlaska iz Zagreba do danas uspjeho (!) da nabavim preko 20 slika za Galeriju. Medju ovim slikaman (!) 


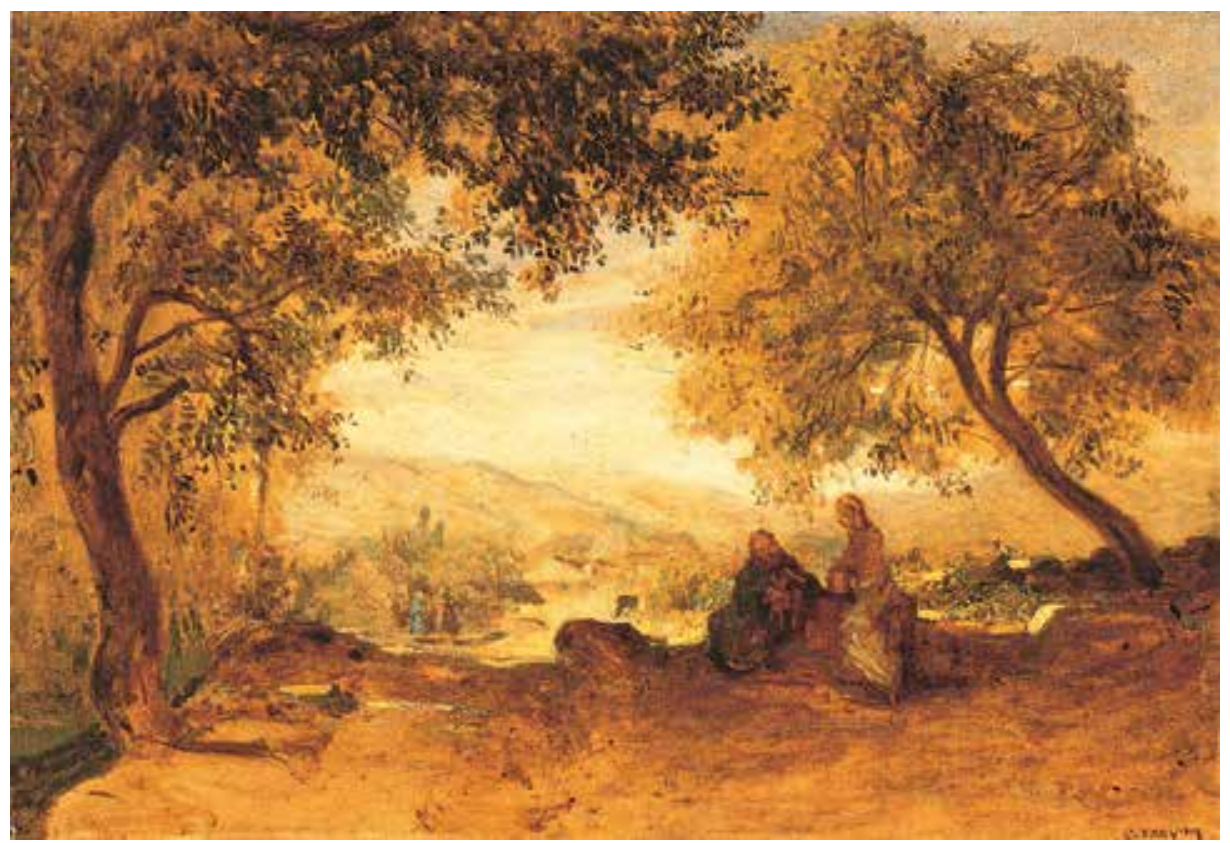

5. Constant Troyon, Krist i Samaritanka, o. 1840., ulje na dasci, 30,8 $\times 44,2 \mathrm{~cm}$, Zagreb, Muzej Mimara, inv. br. ATM 844 (๔ Dokumentacija Muzeja Mimara, foto: Nenad Čaće)

Constant Troyon, Christ and the Samaritan Woman, ca. 1840, oil on panel, $30.8 \times 44.2 \mathrm{~cm}$, Zagreb, Mimara Museum, inv. no. ATM 844)

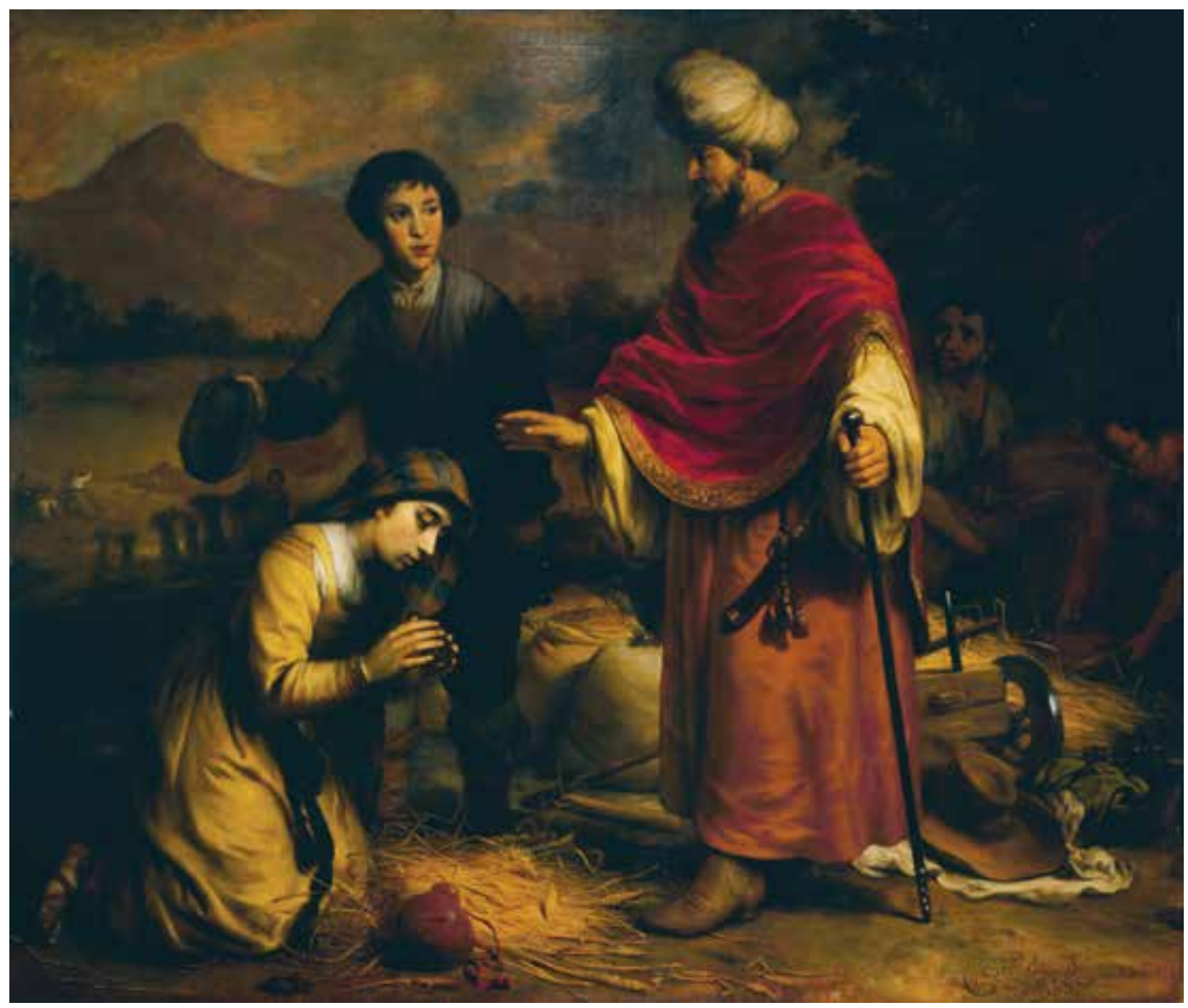

6. Gerbrand van den Eeckhout, Ruta i Boaz, 1661., ulje na platnu, $164 \times 198 \mathrm{~cm}$, Zagreb, Muzej Mimara, inv. br. ATM 2000 (@ Dokumentacija Muzeja Mimara, foto: Nenad Čaće)

Gerbrand van den Eeckhout, Ruth and Boaz, 1661, oil on canvas, $164 \times 198 \mathrm{~cm}$, Zagreb, Mimara Museum, inv. no. ATM 2000 
nalazi se i nekoliko veoma dobri radova od veliki majstora, kao što je Paolo Veronese, Lucas Cranach, Nicola Pousin, Gerard van Eckheut i. t. d. Za ove sam slike izdao 16.435 \$. Slike se većinom nalaze u zgradi naše Vojne misije. ${ }^{34}$ Ipak, s obzirom da nije eksplicirao djela, već samo autore, valja imati na umu da je Topić za Tita nabavio i Eeckhoutovu sliku Davanje desetine koju mu je apostrofirao u gore citiranom pismu o dopremanju umjetnina iz Berlina. ${ }^{35}$

Nakon dolaska u Jugoslaviju 1950. godine slici Ruta i Boaz izgubio se trag, a za njezinu se sudbinu, pitanje smještaja i mogućnost priključivanja Strossmayerovoj galeriji Topić zanimao kod Zlamalika koji je raspolagao fotografijom djela. ${ }^{36} \mathrm{Iz}$ njihove korespondencije saznajemo da je Zlamalik u Zagrebu ušao u trag slici zahvaljujući restauratorskim zahvatima koji su na njoj obavljeni oko 1970 . godine,${ }^{37}$ no njezina sudbina ostaje nepoznata još gotovo dva desetljeća. Slika je najzad 1987. godine "vraćena iz kumrovečke rezidencije i priključena velikoj donaciji« Muzeju Mimara. ${ }^{38}$

U monografskoj obradi slike Ruta i Boaz kustosica Muzeja Helena Zoričić izdvojila je njezinu zastupljenost u ranijoj inozemnoj literaturi te ju je opravdano izjednačila s reprodukcijom publiciranom u Gemälde der Rembrandt Schüler Wernera Sumowskog. ${ }^{39}$ Osim što je afirmirala atribuciju nizozemskom majstoru, svojim je radom pružila i podlogu za istraživanje provenijencije slike. Crpeći podatke iz opsežnog djela Sumowskog, Zoričić je istaknula da je Eeckhoutovo djelo "posljednji put viđeno prije Drugog svjetskog rata $\mathrm{u}$ trgovini umjetnina D. Katz u Dierenu (kraj Arnhema u Holandiji) « i prenijela bilješku o izlaganju slike u Londonu 1879. godine. ${ }^{40} \mathrm{Te}$ je fragmente moguće proširiti novim saznanjima koja ukazuju na bogato dokumentiranu povijest slike tijekom 18., 19. i 20. stoljeća.

U Londonu je slika Ruta i Boaz izložena 1879. godine na tzv. Winter Exhibition u organizaciji Royal Academy of Arts te je u katalogu izložbe detaljno opisana:

80

\section{RUTH AND BOAZ.}

\section{EARL CADOgan. Gerbrant van den Eeckhout.}

Boaz, clad in a yellow dress and red mantle, and white turban on head, stands to l. blessing with $\mathrm{r}$. hand Ruth, who kneels before him ; she is dressed in yellow; a servant and labourers behind them; mountains in distance; dark sky. Signed and dated, on r., "G. V. Eeeckhout Fecit, A. 1661."

Canvas, 58 by 73 in. $^{41}$

Izuzev otklona o smještaju Boaza s lijeve strane, zagrebačka slika posve, uključujući potpis i dataciju u 1661. godinu, odgovara djelu koje je za izložbu posuđeno od Earla Cadogana. $^{42}$ Dimenzije slike navedene $\mathrm{u}$ inčima (približno 147 $\times 185 \mathrm{~cm}$ ) odudaraju desetak-dvadesetak centimetara od dimenzija slike u Muzeju Mimara, no nedvojbenu potvrdu da je riječ o istoj slici pruža naljepnica s izložbe sačuvana na poleđini slike (sl. 7). Slične diskrepancije između dimenzija zagrebačke slike i onih publiciranih u djelu Sumowskoga uočila je već H. Zoričić (4 i $13 \mathrm{~cm}$ ), a dotična bi se odstupanja mogla objasniti ne samo pogreškom u bilježenju nego i ukrasnim, lučno zaključenim okvirom koji je ranije sakrivao sva četiri ruba slike. ${ }^{43}$

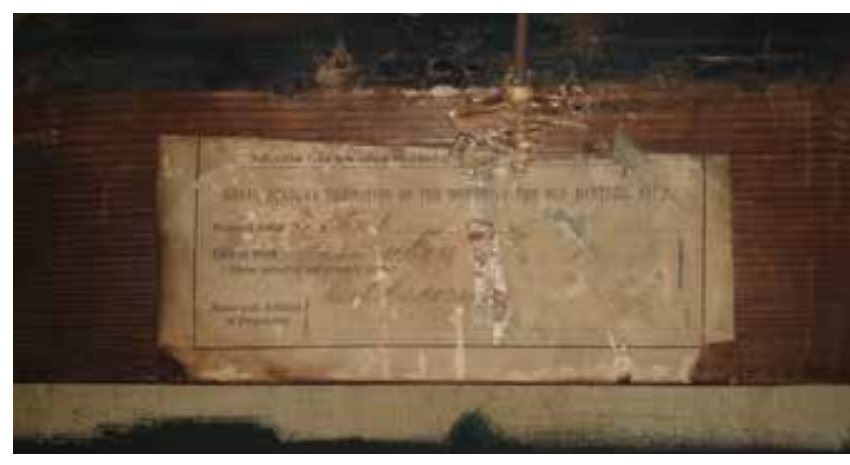

7. Poleđina slike Ruta i Boaz, detalj (foto: Ivan Ferenčak, 2021.) Back of the painting Ruth and Boaz, detail

Sudbina slike od londonske izložbe 1879. godine do 1940-ih kada se za smještaj navodi Kunsthandel D. Katz u Dierenu ostaje nepoznanica, no u tom je periodu ipak prisutna u literaturi. George Isarlov u radu o stvaralaštvu Rembrandtova ozračja donosi sumarne popise djela majstora Rembrandtova kruga, među kojima navodi i Eeckhoutovu »Ruth et Booz (expos. Londres 1879, $\left.\mathrm{n}^{\circ} 80 ; \mathrm{HdG}\right) \ll^{44} \mathrm{U}$ toj kratkoj crtici »HdG « označava, kako navodi u napomeni na početku rada, osobne bilješke povjesničara umjetnosti Cornelisa Hofstede de Groota (1863. - 1930.) dostupne u RKD-u u Den Haagu. ${ }^{45}$ U Hofstede de Grootovoj ostavštini u RKD-u dvije su kartice koje referiraju na Eeckhoutovu sliku izlaganu u Londonu (popis majstorovih slika i prijepis kataloške jedinice londonske izložbe), ${ }^{46}$ a među karticama u tome fondu pronalazimo još jedan detaljan opis Eeckhoutove slike ove teme:

No. 32. Hoog 62 Breed 73,1/2 duim. Doek.

In dit uitmuntend Tafereel ziet men Ruth de Moabitische geknield voor Boaz; dees veel vermogende Man is verbeeld zeer kostbaar gekleed, staande, met eene deftige houding en eene edelmoedigheid in het gelaat, als willende de weldaaden, die Ruth haare Schoonmoeder beweezen heeft, vergelden; zy schynt, met een gebogen hoofd, nedergeslagene oogen, en tezamengevoegde handen, ootmoedig geknield, te betuigen dat zy, als eene vreemde zynde, gevoelig was aangedaan door zyne byzondere goedwilligheid; agter haar, staat de Jongen, die over de Maaijers gesteld was, welke, bloodshoofds, met zyn' Hoed in de regter en Sleutels in de linker hand, op de bevelen zyns Meesters schynt te wagten; eenige Koren-airen, door haar geleezen, leggen voor haar ter zyde; en agter Boaz ziet men een Dienaar eenen Wagen met Garven laadden; tegen hat Bergagtig Verschiet vertoont zit eene Valei, daar, in een veld met Korenairen, eenige Maijers bezig zyn. Gelyk dit een onderwerp van Erkentenis, Eerbied, en dankbaare Ootmoed is, zo heeft deeze groote Meester het licht en Donker, de Kleuren, en de gansche Houding zodanig geschikt, dat ieder Aanschouwer aanstonds, volgens het oogmerk des Meesters, van de daad der Historie getroffen word, waar toe niet weinig medewerker, de verschillende Hartstogten en Standen, dewelke in de Persoonaadjen, die in die Schildery alle op de bevalligste en kragtigste wyze geschilderd zyn, gezien worden.

Yver. f. 750.

Veil. F. van de Velde. Amsterdam, 7 Sept. $1774 .{ }^{47}$ 


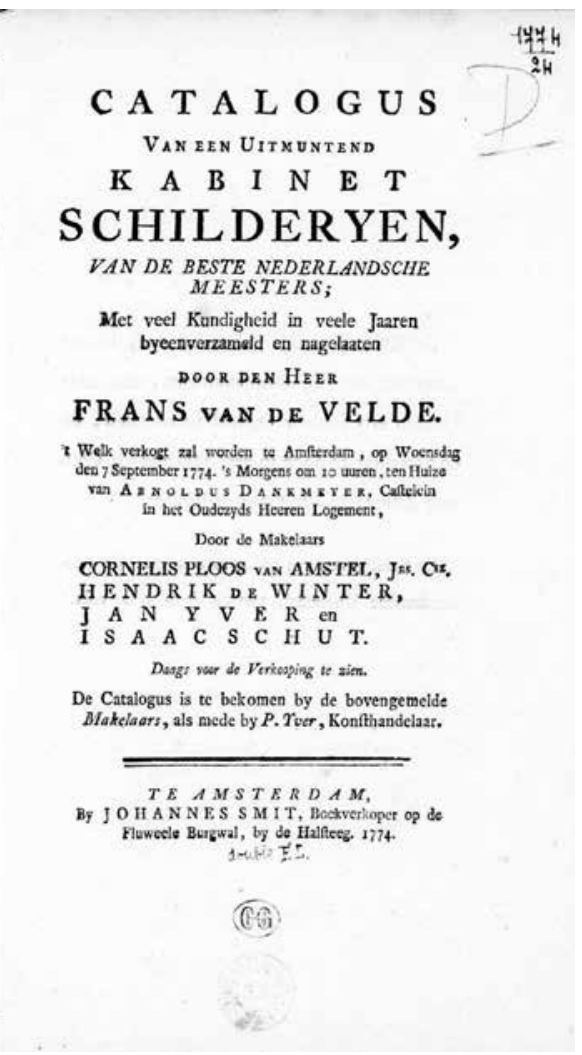

8. Catalogus van een uitmuntend kabinet Schilderyen, van de beste Nederlandsche meesters, met veel kundigheid in veele jaaren byeenverzameld en nagelaaten door den Heer Frans van de Velde (...), Amsterdam, 7. rujna 1774., naslovnica (izvor: https://bibliothequenumerique.inha.fr/idurl/1/18480)

Catalogus van een uitmuntend kabinet Schilderyen, van de beste Nederlandsche meesters, met veel kundigheid in veele jaaren byeenverzameld en nagelaaten door den Heer Frans van de Velde (...), Amsterdam, September 7, 1774, cover page

Iako se i ovdje susrećemo s manjim nepodudarnostima u dimenzijama (navedene su mjere, približno $159 \times 189 \mathrm{~cm}$, desetak centimetara manje od slike u Muzeju Mimara), opisano djelo prilično vjerno odgovara zagrebačkoj slici. Uključujući sliku iz Muzeja Mimara, u opusu Gerbranda van den Eeckhouta evidentirano je šest ulja na platnu s prikazom starozavjetne priče o Ruti i Boazu datiranih između 1651. i 1672. godine. ${ }^{48}$ Među njima srodnu kompoziciju grupe troje istaknutih likova i motiv Rute koja kleči pred Boazom nalazimo jedino na primjeru iz Kunsthalle u Bremenu, no ta je slika bitno manjih dimenzija i na njoj izostaju spomenuti ključevi i kapa koje mladić drži u ruci. ${ }^{49}$

Napomena na kraju kartice upućuje da su podatci prepisani iz kataloga aukcije održane u Amsterdamu 1774. godine, a sudeći prema inicijalnome monogramu $C H d G$ na naslovnici, Hofstede de Groot posjedovao je anotirani primjerak kataloga sačuvan u knjižnici francuskog Nacionalnog instituta za povijest umjetnosti (sl. 8). ${ }^{50} \mathrm{Na}$ aukciji su prodavane slike nizozemskoga kolekcionara Fransa van de Veldea (†1774.), ${ }^{51}$ a Eeckhoutovu je sliku, sudeći prema anotaciji, kupio Yver. $S$ obzirom na izostanak inicijala imena nije jasno o kojem se grafičaru i trgovcu umjetninama radi - ocu Pieteru Yveru
(1712. - 1787.) ili sinu Janu Yveru (1747. - 1814.) koji je na naslovnici istaknut kao jedan od četvorice aukcionara. ${ }^{52}$

Uz bogate kartotečne bilješke koje svjedoče o vlasnicima slike Ruta i Boaz tijekom 18. i 19. stoljeća, nizozemski institut u svojoj bazi RKDimages navodi i podatke o kasnijoj provenijenciji slike, odnosno vlasnike nakon Kunsthandel D. Katz: do 1950. godine za smještaj slike navedena je privatna kolekcija L. Hedeman-Wolff u Almelu, a od 1957. godine kolekcionar i trgovac umjetnina Saam Nijstad (1922. - 2011.). ${ }^{53}$

Ponešto drugačije, preciznije i - imamo li na umu Topićevu nazočnost na njemačkom prostoru kao i podatke o transferu u Jugoslaviju te potvrde kasnijeg smještaja slike unutar države - vjerojatno točnije podatke o intrigantnim smjenama vlasnika slike saznajemo iz internih obrazaca za izjave fondacije SNK. Prema izjavi koju su u svibnju 1946. godine pružili “izvorni” vlasnici »J. Hedeman en echtgenootem, Oostmarsumschestraat, Almelo" slika je pripadala njihovoj zbirci, a u travnju 1943. godine predana je u amsterdamsku banku Lippmann, Rosenthal \& Co.: »Ingeleverd bij Lippmann Rosenthal \& Co (21639/93a) volgens fact. 169 d.d. 28.4.43. Tax waarde f. 6.500.-. Verk.prijs f. 8.500.-. ${ }^{54}$ Obrazac nadalje evidentira da je slika konfiskacijom dospjela kod »Reinheldta $u$ c čijem se posjedu nalazila u trenutku davanja izjave.

Pružatelja informacija prepoznajemo kao industrijalca i kolekcionara Jacquesa Hedemana (1879. - 1948.), ${ }^{55} \mathrm{u}$ čijem je sumarnom popisu zbirke Eeckhoutova slika Ruta i Boaz zavedena među umjetninama koje su se nalazile u njegovoj rezidenciji u Almelu. ${ }^{56}$ Potvrda Hedemanove akvizicije slike u Kunsthandel D. Katz nije pronađena, no prema riječima nasljednika, prijateljevao je s Nathanom Katzom (1893. 1949.), jednim od dvojice braće koji su rukovodili trgovinom iz koje je nabavljao slike za svoju kolekciju prije negoli je raspačana u nacističkim pohodima na Nizozemsku. ${ }^{57} \mathrm{U}$ tome kontekstu banka Lippmann, Rosenthal \& Co. »was far more of a storage depot and sales office for stolen Jewish property than a financial institution. ${ }^{58}$ Preuzimanjem imena renomirane banke prije u židovskom vlasništvu, ta "pljačkaška banka" služila je kao paravan za izvlašćivanje Židova koji su joj prema zakonskoj regulativi bili primorani predati imovinu. ${ }^{59}$ Umjetnine su iz banke Lippmann, Rosenthal \& Co. gotovo trenutačno po zaprimanju prosljeđivane na prodaju, a među "suradnicima" banke u tim je transferima zamjetnu ulogu imao berlinski trgovac umjetnina Curt Reinheldt koji je tijekom 1943. godine iz banke otkupio tridesetak slika iz Hedemanove kolekcije. ${ }^{60}$ Njegovim je posredovanjem slika Ruta i Boaz zasigurno dospjela na njemačko tržište gdje ju je Topić, čini se, nabavio u sklopu akvizicija realiziranih u službi države.

\section{Predmeti iz "restitucija"}

U kontekstu suradnje s jugoslavenskim vlastima, osobitu je pozornost plijenila Topićeva uloga u procesu fabriciranih restitucija. U lipnju 1949. godine Topić je u četiri pošiljke uspio iz Central Collecting Pointa (skraćeno CCP) u Münchenu 


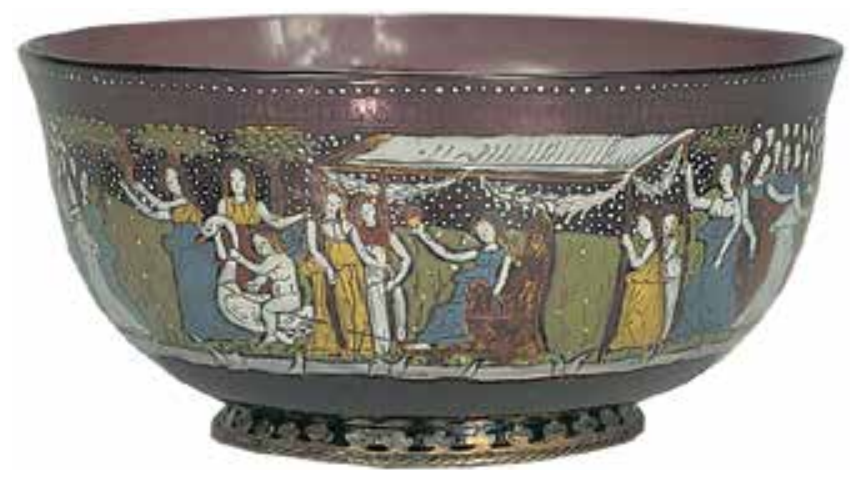

9. Zdjelica, Venecija, o. 1450., prozirno purpurno staklo, višebojni emajl i pozlata, srebro, vis. $6,3 \mathrm{~cm}$, $\varnothing$ otvora 13,5 cm, Muzej Mimara, inv. br. ATM 1783 (๔) Dokumentacija Muzeja Mimara, foto: Nenad Čaće)

Small bowl, Venice, ca. 1450, clear purple glass, multicolour enamel and gilding, silver, height $6.3 \mathrm{~cm}$, opening $\varnothing 13.5 \mathrm{~cm}$, Mimara Museum, inv. no. ATM 1783

otposlati u Jugoslaviju 166 umjetnina, a o svojem je radu obavijestio Tita koji se osobno zanimao za dolazak umjetnina. Na jednom od Topićevih pisama u kojima najavljuje dolazak vlaka u Beograd Tito je tako zabilježio i parafirao: "Javiti kada dođe vagon $\mathrm{T} \ll{ }^{61}$

Dopremanje je četiriju pošiljaka u Beograd dokumentirano, no zbog naknadnog nepoznatog smještaja brojnih predmeta, Topiću se zarana predbacivalo da je pokrao "restitucije". Istražujući dokumentaciju o pristizanju umjetnina u Beograd, Vesna Kusin u Arhivu Jugoslavije pronašla je potvrde o zaprimanju predmeta, osnivanju komisije za evidentiranje pošiljki i stanja predmeta i njihovom djelomičnom raspačavanju te je slijedom dostupne dokumentacije zaključila da nijedan od "restituiranih" predmeta nije završio kod Topića: "Danas se još uvijek ne zna gdje su sva ta djela završila. Kod Mimare sigurno nisu, jer su zaprimljena nakon dolaska u Jugoslaviju. « ${ }^{62}$ Konstantin Akinsha u Muzeju Mimara prepoznao je međutim staklenu zdjelicu kao jedan od 166 "restituiranih" predmeta: »It is a painted-glass Venetian wedding cup, which was dated to the $17^{\text {th }}$ century when it was in the collection of Hermann Goering; Mimara dated it to the $15^{\text {th }}$ century and 'improved' it by adding a gilded silver base. ${ }^{633}$

Venecijanska staklena zdjelica (sl. 9) tematikom naslikane procesije uklapa se u skupinu predmeta vezanih uz svadbene prilike, uglavnom datiranih u drugu polovinu 15 . stoljeća. ${ }^{64}$ U minhenski CCP zdjelica je dospjela početkom kolovoza 1945. godine iz posjeda Hermanna Göringa te je uvedena pod ulaznim, tzv. minhenskim brojem (Mü.-no.) 6298/6. ${ }^{65}$ Inventarna kartica umjetnine (Property Card Art) pruža dvojbeni podatak da je konfiscirana u Jugoslaviji ${ }^{66}$ dok sačuvana fotografija potvrđuje da je staklenoj zdjelici nakon napuštanja CCP-ja pridodano metalno podnožje. ${ }^{67} \mathrm{Zdjelica}$ je iz CCP-ja otpravljena 2. lipnja 1949. godine u tzv. petoj pošiljci koja je obuhvaćala još svega tri predmeta: mošejsku lampu, kasnorimsku kupu i Kuran. ${ }^{68}$

Iz te skupine u fundusu Muzeja Mimara još možemo identificirati mošejsku lampu datiranu u 14. stoljeće (sl. 10). ${ }^{69} \mathrm{U}$ CCP je također pristigla u kolovozu 1945. godine iz Görin-

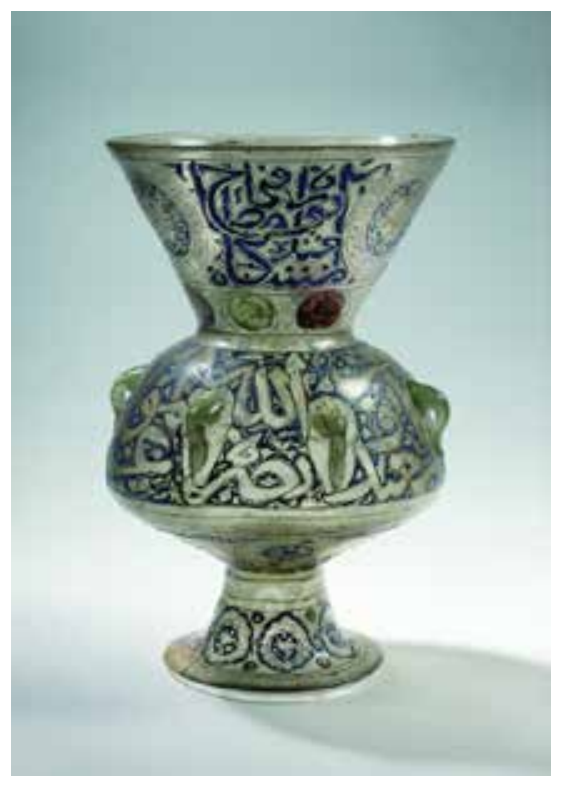

10. Mošejska svjetiljka, Sirija, 14. st., prozirno, smećkasto tonirano staklo, višebojni emajl, vis. $38,3 \mathrm{~cm}$, ø otvora 24,6 cm, Muzej Mimara, inv br. ATM 1435 (@ Dokumentacija Muzeja Mimara, foto: Nenad Čaće) Mosque lamp, Syria, $14^{\text {th }}$ century, transparent brownish-tinted glass, multicolour enamel, height $38.3 \mathrm{~cm}$, opening ø $24.6 \mathrm{~cm}$, Mimara Museum, inv. no. ATM 1435

gova posjeda te je uvedena pod “minhenskim" brojem 7035 . Kao i za zdjelicu, inventarna kartica umjetnina bilježi da je konfiscirana u Jugoslaviji, a dodatnu informaciju o navodnome podrijetlu lampe iz džamije u Bosanskoj Krupi pruža restitucijski zahtjev: »As to the statement of the Vakuf-Merrf comission in Bosanska Krupa the lamp was removed, with other objects, by German troops in 1943. ${ }^{70} \mathrm{Uz}$ stanje i opis predmeta na kartici je zabilježeno da je »foot broken off « $i$ » 1 piece missing «, no primjerak iz zagrebačkog Muzeja posve odgovara predmetu s fotografije. ${ }^{71}$

Izvjesno je da su dva staklena predmeta u Jugoslaviju dospjela Topićevim angažmanom na "restitucijama". S obzirom da su iz Topićeva posjeda prispjeli u Muzej Mimara, ostaje upitno jesu li u Beogradu uopće bili predani, primljeni i preuzeti od strane državne komisije.

Posljednjih godina intenzivirana istraživanja Topićeve kolekcionarske aktivnosti pokazuju da je najranije njegove akvizicije moguće smjestiti na njemački prostor 1930-ih i 1940-ih godina. Na tržištu Trećeg Reicha Ante Topić Mimara skupio je zbirku nedefiniranoga opsega iz koje je stotinu četrdeset umjetnina 1948. godine dokumentirao u fotoalbumima Zbirka slika i skulptura Ante Mimara. Nakon toga prvog obimnijeg prikaza, kolekcija je u sljedećim desetljećima dosegla više tisuća umjetnina, no podatci o dotadašnjim vlasnicima, okolnostima, vremenu i mjestu akvizicija te ranijem vrednovanju svih tih predmeta uglavnom su ostali nepoznati. 
Prikupljeni i novoutvrđeni podatci za četiri slike i dva staklena predmeta umjetničkog obrta iz Muzeja Mimara, predstavljeni u ovome radu, produbljuju poznavanje povijesti tih umjetnina i svjedoče kontinuitetu Topićeva kolekcionarstva u ratnim i poratnim godinama. Rezultati istraživanja prove- nijencije pritom u cjelini doprinose osvjetljavanju formiranja zbirke na kojoj je utemeljen Muzej Mimara, a izabrani primjeri umjetnina uz to ukazuju na različite modele kojima je Topić pribavljao umjetnine te se izdvajaju kao materijalni tragovi za tumačenja osobne povijesti kolekcionara.

\section{Bilješke}

* Ovaj rad financirala je Hrvatska zaklada za znanost projektom IP-2020-02-1356 Istraživanje provenijencije umjetnina u zagrebačkim zbirkama (ZagArtColl_ProResearch).

\section{1}

Usp. LADA RATKOVIĆ BUKOVČAN, Muzej Mimara: 30 godina djelovanja, u: Muzej Mimara: 30 godina djelovanja - 30 godina $s$ vama (ur. Lada Ratković Bukovčan), Zagreb, 2017., 14-31.

2

Usp. KONSTANTIN AKINSHA, Ante Topic Mimara: 'The Master Swindler of Yugoslavia', ARTnews (2001.), dostupno na: https://www.lootedart.com/MFEU4T15383 (12.6. 2019.); BRIAN SEWELL, Museums of Zagreb, u: Croatia. Aspects of Art, Architecture and Cultural Heritage, London, 2009., 194-207, 194-198; JONATHAN PETROPOULOS, Five Uncomfortable and Difficult Topics Relating to the Restitution of Nazi-Looted Art, New German Critique, 130 (2017.), 125-142, 127.

3

Usp. SLAVKO ŠTERK, Pitanja o atribuciji: osvrt na zbirke ikona, talijanskog i španjolskog slikarstva u okviru donacije Ante Topića Mimare, Odjek [Sarajevo], 1. - 15. lipnja 1985., 9-10; SLAVKO ŠTERK, Deset ikona iz Zbirke Ante Topića-Mimare, Vijesti muzealaca i konzervatora Hrvatske, 36/1-2 (1987.), 32-36; SLAVKO ŠTERK, Osam slika talijanskih majstora cinquecenta iz zbirke Ante Topića-Mimare, Vijesti muzealaca i konzervatora Hrvatske, 36/3-4 (1987.), 8-15; SLAVKO ŠTERK, Nekoliko slika španjolskih majstora iz Zbirke Ante Topića-Mimare, Vijesti muzealaca $i$ konzervatora Hrvatske, 38/1-2 (1989.), 8-13.

4

Usp. HELENA ZORIČIĆ, Tondo Domenica Beccafumija [Studije Muzeja Mimara, sv. 10], Zagreb, 1997.; LJERKA DULIBIĆ, Sulla provenienza dal Camposanto pisano di una Presentazione al Tempio nel Museo Mimara di Zagabria (e di un Angelo della Maestà di Duccio), Predella: Primitivi pisani fuori contesto, 1 (2010.), 97-104, XLII-XLVII; SLAVEN PEROVIĆ, Oznake zbirki na crtežima iz Muzeja Mimara i na bakropisu iz jedne hrvatske privatne zbirke [Studije Muzeja Mimara, sv. 39], Zagreb, 2011., 25-46; KREŠIMIR JURAGA, Iza slike - novi pogled na djela iz fundusa Muzeja Mimara, virtualna izložba, 2021., dostupno na: https://blog.mimara.hr/2021/01/19/iza-slike-novi-pogled-nadjela-iz-fundusa-muzeja-mimara/ (5. 2. 2021.).

\section{5}

Usp. IVAN FERENČAK, Umjetnine iz zbirke Ante Topića Mimare u Strossmayerovoj galeriji, doktorska disertacija (Sveučilište u Zadru), Zadar, 2021.

6

Usp. IVAN FERENČAK, Od 'Zbirke slika i skulptura Ante Mimara' do Zbirke starih majstora Strossmayerove galerije, u: Odabrana djela iz donacije Ante Topića Mimare Strossmayerovoj galeriji starih majstora HAZU (ur. Ljerka Dulibić - Iva Pasini Tržec), Zagreb, 2018., 14-41, 14-18.

\section{7}

Usp. SLAVKO ŠTERK, Deset ikona... (bilj. 3, 1987.), 33; SLAVKO ŠTERK (bilj. 3, 1989.), 8.

8 Usp. VESNA KUSIN, Mimara, Zagreb, 1987., 49; ANDREW DECKER, Real and Fake in the 'Zagreb Louvre', ARTnews (1987.), 151-158, 156.

9 Usp. SLAVKO ŠTERK, Osam slika... (bilj. 3, 1987.), 12. Vidi: HUGO HELBING, Sammlung Geheimrat Ottmar Strauss, Teil II: Aus Haus Bayenthalgürtel 2 in Köln und aus Haus Heisterberg; Sammlung Schwarz, Berlin, Nachlass Geheimrat W. Preetorius, Mainz und anderer Besitz, aukcijski katalog br. 45, Frankfurt, 22.-24. svibnja 1935., 7 (kat. br. 24), tabl. 11.

10 Usp. HUGO HELBING (bilj. 9), [4], 7 (kat. br. 27), tabl. 11.

11

Usp. Preisberichte, Weltkunst, IX/23 (9. lipnja 1935.), 3; ANGELIKA ENDERLEIN, Der Berliner Kunsthandel in der Weimarer Republik und im NS-Staat: zum Schicksal der Sammlung Graetz, Berlin, 2006., 87-91.

12

Usp. Vodič kroz dio zbirke Ante Topića-Mimare (ur. Mijo Antunović - Karolina Franc), Zagreb, 1983., 43 (kat. br. 56). U muzejskim publikacijama triptih je razmatran kao rad Boscheve radionice odnosno sljedbenika. Usp. Muzej Mimara: Zbirka umjetnina Ante $i$ Wiltrud Topić (ur. Tugomir Lukšić), Zagreb, 1989. (2. izd.), 388 (kat. br. 1.120); Vodič Muzeja Mimara (ur. Tugomir Lukšić), Zagreb, 2007. (3. revid. izd.), 158 (kat. br. 252).

13

Usp. JOS KOLDEWEIJ, ...A Man like Bosch..., u: Jheronimus Bosch, his sources: $2^{\text {nd }}$ International Jheronimus Bosch Conference, May 22-25, 2007, 's-Hertogenbosch (ur. Jo Timmermans), 's-Hertogenbosch, 2010., 16-29, 21-23. Goran Petrinić evidentirao je u privatnoj kolekciji još jednu, bitno slabiju inačicu u formi triptiha pripisanu Boschevu krugu. Usp. GORAN PETRINIĆ, Konzervatorsko-restauratorska dokumentacija: Radionica Hieronymusa Boscha, Silazak u Limb..., Zagreb, 2017., 14-15.

14

Usp. MATTHIJS ILSINK et al., Hieronymus Bosch, Painter and Draughtsman: Catalogue Raisonné, Brussels, 2016.

15

Usp. RUDOLF TH. M. VAN DIJK, Toward Imageless Contemplation: Gerard Zerbolt of Zutphen as Guide for 'Lectio Divina', $\mathrm{u}$ : Spirituality Renewed: Studies on Significant Representatives of the Modern Devotion (ur. Hein Blommestijn - Charles Caspers - Rijcklof Hofman), Leuven, 2003., 3-28. 
16

RUDOLPH LEPKE'S KUNST-AUCTIONS-HAUS, Gemalde alter und neuerer Meister: Antiquitaten, japanische und chinesische Arbeiten, Skulpturen, Mobel, Teppiche, Tappisserien, aukcijski katalog br. 2109, Berlin, 11. - 12. prosinca 1936., 14 (kat. br. 87).

17

Usp. IVA PASINI TRŽEC, Prema: Balthasar van den Bossche, Slikarski atelijer, u: Odabrana djela iz donacije Ante Topića Mimare Strossmayerovoj galeriji starih majstora HAZU (ur. Ljerka Dulibić - Iva Pasini Tržec), Zagreb, 2018., 132-139, 138.

18

Usp. IVAN FERENČAK, Slike iz donacije Ante Topića Mimare Strossmayerovoj galeriji starih majstora u aukcijskim katalozima kuće Lempertz iz Kölna (1933.-1943.), Peristil, 61 (2018.), 175-194.

19

Anotirani primjerak u knjižnici RKD-a zaveden je pod signaturom 201900866.

20 Usp. RUDOLPH LEPKE'S KUNST-AUCTIONS-HAUS (bilj. 16), [4], 13-14 (kat. br. 85-88).

21 Usp. Vodič kroz dio zbirke... (bilj. 12), 21 (kat. br. 26), 43 (kat. br. 56). 22

Usp. IVAN FERENČAK, Prema: Cornelis Bega, Sat glazbe, u: Odabrana djela iz donacije Ante Topića Mimare Strossmayerovoj galeriji starih majstora HAZU (ur. Ljerka Dulibić - Iva Pasini Tržec), Zagreb, 2018., 114-119, 116; IVAN FERENČAK (bilj. 18); IVAN FERENČAK, Tržište umjetnina pod okriljem nacističkog režima, u: TransCultAA istraživanja u Strossmayerovoj galeriji (ur. Iva Pasini Tržec), Zagreb, 2020., 78-83.

23

Usp. LJERKA DULIBIĆ - IVA PASINI TRŽEC, A New Contribution to Trecento Painting at Strossmayer Gallery in Zagreb, u: Scripta in honorem Igor Fisković: zbornik povodom sedamdesetog rodendana $=$ Festschrift on the occasion of his 70th birthday (ur. Miljenko Jurković - Predrag Marković), Zagreb - Motovun, 2015., 165-172, 170-171.

\section{4}

Usp. IRIS LAUTERBACH, The Central Collecting Point in Munich: A New Beginning for the Restitution and Protection of Art, Los Angeles, 2018., 123. O de Beaufortu vidi i tekst: René François Paul de Beaufort (1889-1969), na mrežnim stranicama Monuments Men Foundation for the Preservation of Art, https://www. monumentsmenfoundation.org/de-beaufort-jhr-rene-francoispaul (27. 4. 2021.).

25

National Archives and Records Administration, Washington D.C. (dalje: NARA), M1946, Records Concerning the Central Collecting Points ('Ardelia Hall Collection'): Munich Central Collecting Point, 1945-1951 (dalje: M1946), roll 134, R. F. P. de Beaufort, Fieldtrip to Nurnberg and Hersbruck, 28. studenoga 1946., dostupno na: https://www.fold3.com/image/270142175 (27. 4. 2021.).

26

Usp. http://www.herkomstgezocht.nl/en/infosnk (27. 4. 2021.).

27

Usp. NARA, M1944, Records of the American Commission for the Protection and Salvage of Artistic and Historic Monuments in War Areas (The Roberts Commission), 1943-1946, roll 093, Art Looting Investigation Unit Final Report, Washington, D.C., 1. svibnja 1946., 145, dostupno na: https://www.fold3.com/image/273355400 (27.4. 2021.).
28

Usp. http://www.herkomstgezocht.nl/en/vw-collection/landschap-met-christus-aan-de-bron-0; http://www.herkomstgezocht.nl/en/vw-collection/markt-een-dorpsstraat-0 (27.4. 2021.).

29

Usp. IVAN FERENČAK, Ante Topić Mimara’s Multifaceted Roles in Transferring Artworks Across Borders, u: Transfer of Cultural Objects in the Alpe Adria Region in the $20^{\text {th }}$ Century (ur. Christian Fuhrmeister - Barbara Murovec), Köln, 2022. (u tisku).

30

Arhiv Jugoslavije, Beograd (dalje: AJ), fond 863, Kancelarija Maršala Jugoslavije (dalje: KMJ), III-4/16, Ante Topić Mimara Josipu Brozu Titu, Frankfurt, 24. ožujka 1950.

31

Arhiv Strossmayerove galerije, Zagreb (dalje: ASG), registrator Donacija Mimara, Predstavka - Ante Topić Mimara Saveznoj skupštini SFR Jugoslavije, Salzburg [rujan 1966.]. Usp. VESNA KUSIN (bilj. 8), 122-123.

32

O problematici pošiljke iz Berlina u Beograd u veljači 1950. godine vidi: IVAN FERENĆAK (bilj. 5), 24-31.

33

ASG, registrator Donacija Mimara, Ante Topić Mimara Vinku Zlamaliku, München, 10. veljače 1969. Usp. još ASG, registrator Donacija Mimara, Ante Topić Mimara Vinku Zlamaliku, Salzburg, 6. veljače 1970.

34

AJ, fond 836 (KMJ), III-4/15, Ante Topić Mimara Josipu Brozu Titu, Berlin, 12. siječnja 1949. Topić je u Zagrebu vjerojatno boravio nakon pisma kojim general Ivan Gošnjak početkom kolovoza 1948. godine obavještava Tita o transportu Topićevih umjetnina iz Berlina. Usp. IVAN FERENČAK (bilj. 5), 19-22.

35

Slika je prije desetak godina prepoznata kao jedna od umjetnina koje su se nalazile u Titovoj beogradskoj rezidenciji u Užičkoj ulici 15 te je uključena na izložbu Pusen i petokraka: zbirka slika druga predsednika. Usp. NENAD RADIĆ, Pusen i petokraka: zbirka slika druga predsednika, Novi Sad, 2012., 34-39.

36 Usp. ASG, registrator Donacija Mimara, Ante Topić Mimara Vinku Zlamaliku, Salzburg, 4. ožujka 1970.; ASG, registrator Donacija Mimara, Vinko Zlamalik Upravi JAZU, Zagreb, 6. studenoga 1969.

37

Usp. ASG, registrator Restauracija-izložbe, Vinko Zlamalik Anti Topiću Mimari, Zagreb, 3. veljače 1970.; ASG, registrator Restauracijaizložbe, Vinko Zlamalik Anti Topiću Mimari, Zagreb, 21. travnja 1970.

38

VESNA KUSIN (bilj. 8), 203.

39

Usp. HELENA ZORIČIĆ, Gerbrand van den Eeckhout, Ruth i Boas, u: Studije Muzeja Mimara, 9 (1993.); WERNER SUMOWSKI, Gemälde der Rembrandt-Schüler: in vier Banden und einem Supplement-Band, 2, Landau in der Pfalz, 1983., 795.

40

HELENA ZORIČIĆ (bilj. 39), 6-7.

41

Exhibition of Works by the Old Masters, and by Deceased Masters of the British School Including Oil Paintings, Miniatures, and Drawings: Winter Exhibition, Tenth Year, katalog izložbe, London, 1879., 19 (kat. br. 80). 
42

Na početku kataloga stoji napomena: »The terms 'right' and 'left' in all descriptions, except those of portraits, denote the right and left of the spectator.«, Exhibition of Works... (bilj. 41), [5].

43 Usp. HELENA ZORIČIĆ (bilj. 39), 6.

44

GEORGE ISARLOV, Rembrandt et son entourage, La Renaissance (srpanj - rujan 1936.), 1-50, 49.

45

»...quand les trois lettres HdG ne sont pas suivies d'un numéro, cela signifie que le renseignement qui les précède a été puisé dans les notes personnelles de $\mathrm{HdG}$, mises à la disposition des travailleurs, à La Haye, à l'Institut, dirigé avec tant de maîtrise par le Dr Hans Schneider.« GEORGE ISARLOV (bilj. 44), 3. O karticama Hofstede de Groota u RKD-u vidi: IVA PASINI TRŽEC, Dvije slike Vaza s cvijećem u Strossmayerovoj galeriji starih majstora u Zagrebu, Radovi Instituta za povijest umjetnosti, 40 (2016.), 79-86, 81.

46

Usp. NL-HaRKD.0351, Archief Fichescollectie Cornelis Hofstede de Groot, Den Haag (dalje: NL-HaRKD.0351), kut. 85, kartica br. 1146773 i kartica br. 1147976, dostupno na: https://rkd.nl/ explore/excerpts/146460 i https://rkd.nl/explore/excerpts/147655 (5. 5. 2021.)

47

NL-HaRKD.0351, kut. 85, kartica br. 1146764, dostupno na: https://rkd.nl/explore/excerpts/146451 (5. 5. 2021.).

48

Usp. RAINER ROY, Studien zu Gerbrand van den Eeckhout, doktorska disertacija (Universität Wien), Wien, 1972., 214-215 (kat. br. 24-29); WERNER SUMOWSKI (bilj. 39), 719, kat. br. $409,420,423,432,460,485$.

49

Gerbrand van den Eeckhout, Ruta i Boaz, 1651., ulje na platnu, 52,7 × 61,5 cm, sign. d.l.k. G. v. Eeckhout. F. / Ao 1651, Kunsthalle Bremen, inv. br. 37-1856. Usp. GUSTAV PAULI, Katalog der Gemälde und Bildhauerwerke in der Kunsthalle zu Bremen, Bremen, 1907., 17.

50

Catalogus van een uitmuntend kabinet Schilderyen, van de beste Nederlandsche meesters, met veel kundigheid in veele jaaren byeenverzameld en nagelaaten door den Heer Frans van de Velde..., aukcijski katalog, Amsterdam, 7. rujna 1774., 14-15 (kat. br. 32), dostupno na: https://bibliotheque-numerique.inha.fr/ idurl/1/18480 (5. 5. 2021.)

51

Usp. RKDartists\&, https://rkd.nl/explore/artists/476644 (5. 5. 2021.).

52

Usp. RKDartists\&, https://rkd.nl/explore/artists/40948; RKDartists\&, https://rkd.nl/explore/artists/331935 (5. 5. 2021.).

53

Usp. RKDimages, https://rkd.nl/explore/images/236203 (5. 5. 2021.).

54

Usp. http://www.herkomstgezocht.nl/en/vw-collection/boaz-enruth (5. svibnja 2021.). Na poleđini platna dvije su brojčane oznake: uz gornji rub plavom bojom ispisan broj najvećim je dijelom prekriven crnim premazom, no neke djelomično vidljive brojke podudarne su broju navedenom u obrascu; u gornjem desnom uglu bijelom je kredom ispisano »№ 93«. Broj » 21639 « redovito se javlja uz predmete iz Hedemanove zbirke. Usp. http://www. herkomstgezocht.nl/en/nk-collection/portrait-woman-small-dog (5. 5. 2021.).

55

Usp. RUDI EKKART - EELKE MULLER, Roof \& restitutie: de uittocht en gedeeltelijke terugkeer van nederlands kunstbezit tijdens en na de tweede wereldoorlog, Deventer, 2017., 58. Napomena L. Hedeman-Wolff u podatcima o provenijenciji RKD-a zasigurno se odnosi na Jacquesovu šogoricu Libertu Hedeman-Wolff (1878. - 1949.). Usp. https://www.joodsmonument.nl/nl/page/265007/ liberta-hedeman-wolff (5. 5. 2021.).

56

Tipkopisni popis Lijst schilderijen J. Hedeman, Almelo sačuvan je u knjižnici RKD-a pod signaturom 20011234.

57

Usp. WIM GOORHUIS, Almelose naziroofkunst hing in ambassade Madrid, Tubantia, 3. listopada 2018., dostupno na: https:// www.tubantia.nl/almelo/almelose-naziroofkunst-hing-in-ambassade-madrid a23be02d/ (5. svibnja 2021.). O Kunsthadel D. Katz vidi: RUDI EKKART - EELKE MULLER (bilj. 55), 22, 38.

58

GERARD AALDERS, Nazi Looting: The Plunder of Dutch Jewry During the Second World War, Oxford - New York, 2004., 127.

59

Usp. GERARD AALDERS (bilj. 58); RUDI EKKART - EELKE MULLER (bilj. 55), 53.

60

Usp. GERARD AALDERS (bilj. 58), 140, 186-189; http://www. herkomstgezocht.nl/en/search/collection/Hedeman\%20Reinheldt (5. 5. 2021.).

61

AJ, fond 836 (KMJ), III-4/15, Ante Topić Mimara Josipu Brozu Titu, [München?], (1. 6. 1949.).

62

VESNA KUSIN, Zagonetni kolekcionar s diplomatskim pasošem, Vjesnik, 30. travnja 1987. Usp. VESNA KUSIN (bilj. 8), 111-115.

63

Usp. KONSTANTIN AKINSHA (bilj. 2).

64

Usp. LADA RATKOVIĆ-BUKOVČAN, Venecijansko staklo muzeja Mimara, Zagreb, 1996., 59 (kat. br. 2); INÊS COUTINHO - LUÍS C. ALVES - TERESA MEDICI, The Broken Piece of a Larger Picture: A Renaissance Enameled Glass Fragment Depicting a Triumphal Procession, Journal of Glass Studies, 61 (2019.), 87-96, 88-90.

65

O sustavu inventiranja u CCP-ju vidi: ANGELIKA ENDERLEIN - MONIKA FLACKE, Database on the Munich Central Collecting Point, dostupno na: https://www.dhm.de/datenbank/ccp/ dhm_ccp.php?seite=9 (14. 4. 2021.).

66

Usp. NARA, M1946, roll 055, Property Card Art [Mü.-no. 6298/6], dostupno na: https://www.fold3.com/image/270070093 (14. 4. 2021.).

67

Fotografija je dostupna na: https://www.fold3.com/image/270070108 (14. 4. 2021.). 
68

Usp. NARA, M1946, roll 028, Schedule „A“, dostupno na: https:// www.fold3.com/image/269971312 (14. 4. 2021.).

69

Usp. LADA RATKOVIĆ-BUKOVČAN, Odabrani primjerci islamskog stakla u Muzeju Mimara, u: Studije Muzeja Mimara, 24 (2006.), 21-23.
70

Usp. NARA, M1946, roll 055, file Yugoslavia: Munich 7035/ Berchtesgaden 1985 [Property Card], dostupno na: https://www. fold3.com/image/270070920 (14. 4. 2021.).

71 Fotografija je dostupna na: https://www.fold3.com/image/270070932 (14. 4. 2021.).

\section{Summary}

Ivan Ferenčak

\section{On the Provenance of Several Artworks at the Mimara Museum in Zagreb}

The Mimara Museum, opened in Zagreb in 1987, is based on a collection of over 3,500 items donated by Ante Topić Mimara (1898-1987) to the state. This voluminous gift is, however, greatly burdened by the unexplained provenance of a number of artworks, as the information on their previous owners and the circumstances of acquisition are generally missing. Recent research has shown that Topić's earliest acquisitions were made in Germany during the 1930s and 1940s. In 1967, he donated a small group of artworks he had collected to the Strossmayer Gallery of Old Masters at the Croatian Academy of Sciences and Arts (HAZU) in Zagreb. For a considerable number of these paintings, the circumstances in which he acquired them on the art market of the Third Reich, creating his collection, have been clarified. This paper brings some details concerning the earlier provenance of six artworks at the Mimara Museum, aimed at supplementing our knowledge on Topić's mechanisms of art acquisition.

In the auction catalogues from the 1930s, two paintings from the Mimara Museum have been identified: The Virgin and Child (Fig. 1) by Giuliano Bugiardini is reproduced in the 1935 catalogue of the auction house Hugo Helbing, while in the following year, in the catalogue of the auction house Lepke, one finds listed the triptych Christ's Descent into Limbo (Fig. 3), painted by a follower of Hieronymus Bosch and known in several versions. Although it is not reproduced there, the triptych's dimensions and the integration of the central image with the text on the wings fully correspond to the described work. The Painter's Atelier from the donation to the Strossmayer Gallery has been noticed earlier as listed for the same auction, and the presence of several works owned by Topić at the same auction- which is the case more than once - supports the conclusion that the acquisitions were made at that time.

In the mid-1940s, we learn from a report by René F.P. de Beaufort (1889-1969) that Topić bought two paintings from Karl Arndt of Hersbrück. An analysis of the sources has established that one of them was Christ and the Samaritan
Woman (Fig. 5) by Constant Troyon, which stands out as a unique example among the artworks of known location for which there is archival data on Topićs direct acquisition. Before the end of 1945, the painting was "willingly sold" to Arndt by the Dutch art dealer Dirk Albert Hoogendijk (1895-1975).

During the war years, Gerbrand van den Eeckhout's Ruth and Boaz (Fig. 6), a painting with richly documented history during the $18^{\text {th }}, 19^{\text {th }}$, and $20^{\text {th }}$ centuries, was brought to the Third Reich and later to Yugoslavia from the Netherlands. In the $18^{\text {th }}$ century, it was in the collection of Frans van de Velde $(\dagger 1774)$, from where it was auctioned in Amsterdam as part of his legacy in 1774 and bought by the graphic artist and art dealer Yver. It was later exhibited at the Winter Exhibition of 1879 in London, for which it was borrowed from Earl Cadogan. Around 1940, it is documented at the Kunsthandel D. Katz in Dieren, from where it was most likely directly included in the collection of the industrialist and collector Jacques Hedemann (1879-1948). Following the occupation of the Netherlands, Hedeman had to hand it over to the "robbery bank" of Lippmann, Rosenthal \& Co. in Amsterdam, where it fell into the hands of the Berlin art dealer Curt Reinheldt in 1943. It was through his mediation that the painting reached the German market, where Topić apparently bought it in the late 1940s. In 1950, the painting was brought to Yugoslavia as part of Topić's acquisitions made in the service of the state and Josip Broz Tito.

In the late 1940s and in 1950, Topić collaborated intensively with the Yugoslav state leadership and participated in the process of fabricated restitutions of artworks. In June 1949, he sent 166 works of art to Yugoslavia from the Central Collecting Point in Munich. The "restituted" works of art were handed over and taken over by the state commission in Belgrade, so it stays unclear how two glass objects (Figs. 9 and 10) entered the Mimara Museum from Topić' s possession.

Keywords: Mimara Museum, Ante Topić Mimara, private collections, provenance of artworks, art market 